\title{
Diagnosis and management of non-immune hydrops in the newborn
}

\author{
Terence Stephenson, Jane Zuccollo, Mich Mohajer
}

Non-immune hydrops fetalis is a relatively rare and complex disorder that requires detailed investigation and coordinated management by a multidisciplinary team. There is a lack of clear advice in the literature on the immediate management and investigation of neonatal hydrops. The approach described here has been used in our unit and has been welcomed, particularly by resident staff.

Hydrops fetalis is associated with a large number of pathologies (see table 1) that are usually divided into:

(1) Immunological. Anaemia results from maternal isoimmunisation against rhesus or other red cell antigens. The antenatal and postnatal aspects of investigation and management of immune hydrops are well covered in standard obstetric and neonatal textbooks. This condition is now extremely rare in our experience, less than 1:10000 deliveries, as a result of improved antenatal intervention.

(2) Non-immunological. Most cases of hydrops fetalis are now non-immunological. A wide range of associations have been reported in over 500 cases $^{1-12}$ but the commonest are chromosomal abnormalities, cardiac anomalies, pulmonary abnormalities, infection and multiple births. In earlier series, no cause was found in approximately $50 \%$ of these cases, ${ }^{3} 13$ but more recent data suggest that with a complete prenatal and postnatal evaluation, ${ }^{25}$ a precise diagnosis can be arrived at in $85 \%{ }^{14}$ Approximately $40 \%$ of cases will have another congenital abnormality. ${ }^{3}$ The remainder of this article refers only to nonimmunological hydrops and is intended to provide guidelines for staff confronted with a hydropic infant at birth.

\section{Obstetric considerations}

Hydrops occurs more commonly if the mother has had a previous stillbirth or hydropic infant. There is also a greater incidence in twin pregnancies, particularly monochorionic twins between which twin-twin transfusion has occurred, or if there is polyhydramnios. ${ }^{9}$ Antenatal diagnosis is usually made by ultrasound examination, which should be a detailed scan looking at growth, liquor volume, cardiac structure, ${ }^{4} 1516$ rate and rhythm and anatomical abnormalities, including features that may point to chromosomal abnormalities. If fetal hydrops is found on

Table 1 Reported associations with fetal hydrops (not necessarily the cause of the hydrops)

Department of Child Health, University Hospital, Nottingham and Department of Neonatal Medicine and Surgery, City Hospital, Nottingham

Terence Stephenson

University Hospital, Nottingham,

Department of

Pathology

Jane Zuccollo

Department of

Obstetrics

Mich Mohajer

Correspondence to:

Dr Terence Stephenson,

Department of Child Health, University Hospital, Nottingham NG7 2UH

No reprints available.

\begin{tabular}{|c|c|c|c|}
\hline $\begin{array}{l}\text { Cardiovascular: } \\
\text { Truncus arteriosus } \\
\text { Calcific myocarditis (Coxsackie } \\
\text { infection) } \\
\text { Arterial calcification } \\
\text { Supraventricular tachycardia } \\
\text { Heart block (mother with } \\
\text { systemic lupus or anti-Ro } \\
\text { antibody) } \\
\text { Hypoplastic left heart } \\
\text { Endocardial fibroelastosis } \\
\text { Septal defects } \\
\text { Pulmonary atresia } \\
\text { Asplenia syndrome } \\
\text { Large atrioventricular } \\
\text { malformation } \\
\text { Premature closure of the } \\
\text { foramen ovale } \\
\text { Premature closure of the ductus } \\
\text { arteriosus (maternal } \\
\text { indomethacin) } \\
\text { Cardiac tumour (usually } \\
\text { rhabdomyoma) } \\
\text { Idiopathic arterial calcification } \\
\text { Any cause of cardiac failure in } \\
\text { utero }\end{array}$ & $\begin{array}{l}\text { Gastrointestinal: } \\
\text { Jejunal atresia } \\
\text { Mid-gut volvulus } \\
\text { Meconium peritonitis } \\
\text { Hepatic fibrosis } \\
\text { Polycystic disease of the liver } \\
\text { Biliary atresia } \\
\text { Hepatic vascular malformations } \\
\text { Familial cirrhosis with portal } \\
\text { hypertension } \\
\text { Genitourinary: } \\
\text { Congenital nephrotic syndrome } \\
\text { Urethral obstruction and renal } \\
\text { dysplasia } \\
\text { Polycystic kidneys } \\
\text { Renal vein obstruction } \\
\text { Congenital abnormalities of the } \\
\text { vagina and uterus } \\
\text { Haematological: } \\
\text { Twin to twin transfusion } \\
\text { syndrome } \\
\text { Rhesus isoimmunisation } \\
\text { Fetomaternal haemorrhage } \\
\text { (positive Kleihauer test) } \\
\text { Homozygous alpha thalassaemia } \\
\text { Fetal anaemia of any cause } \\
\text { Glucose-6-phosphate } \\
\text { dehydrogenase deficiency } \\
\text { Lymphatic: } \\
\text { Congenital lymphangiectasia } \\
\text { Cystic hygroma of the neck }\end{array}$ & $\begin{array}{l}\text { Infective: } \\
\text { Parvovirus } \\
\text { Cytomegalovirus } \\
\text { Toxoplasmosis } \\
\text { Syphilis } \\
\text { Leptospirosis } \\
\text { Chagas' disease } \\
\text { Congenital hepatitis } \\
\text { Respiratory: } \\
\text { Congenital diaphragmatic } \\
\text { hernia } \\
\text { Congenital cystic adenomatoid } \\
\text { malformation } \\
\text { Hamartoma } \\
\text { Tracheo-oesophageal fistula } \\
\text { Atresia of the right main } \\
\text { bronchus } \\
\text { Neurological: } \\
\text { Encephalocele } \\
\text { Agenesis of the corpus } \\
\text { callosum } \\
\text { Tuberose sclerosis } \\
\text { Arthrogryposis } \\
\text { Skeletal: } \\
\text { Osteogenesis imperfecta } \\
\text { Asphyxiating thoracic } \\
\text { dystrophy } \\
\text { Thanatophoric dwarfism } \\
\text { Achondrogenesis } \\
\text { Hypophosphatasia } \\
\text { Saldino-Noonan dwarfism }\end{array}$ & $\begin{array}{l}\text { Placenta/umbilical } \\
\text { cord: } \\
\text { True knot in the cord } \\
\text { Umbilical vein } \\
\text { thrombosis } \\
\text { Large chorioangioma } \\
\text { of the placenta } \\
\text { Aneurysm of the } \\
\text { umbilical artery } \\
\text { Metabolic/storage: } \\
\text { Gaucher's disease } \\
\text { Maternal: } \\
\text { Diabetes } \\
\text { Toxaemia } \\
\text { Drugs (for example } \\
\text { indomethacin) } \\
\text { Miscellaneous: } \\
\text { Retroperitoneal } \\
\text { fibrosis }\end{array}$ \\
\hline
\end{tabular}


Table 2 Antenatal maternal investigations. The specimen bottles and volume required may vary from one laboratory to another

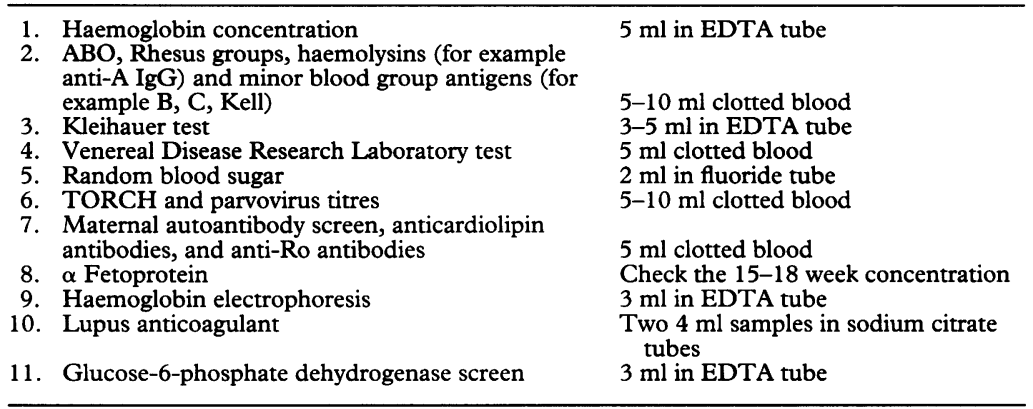

scanning (there may be any combination of ascites, pleural effusion, pericardial effusion, generalised skin oedema of more than $5 \mathrm{~mm}$ or placental oedema), the minimum appropriate maternal antenatal investigations are listed in table 2.4917 Fetal tachyarrhythmia, most commonly supraventricular tachycardia, leading to hydrops fetalis may be intermittent and can therefore be missed by a single ultrasound scan. If suspected, repeated ultrasound scans or a 24 hour cardiotocograph should be undertaken.

\section{ANTENATAL MANAGEMENT}

It may be appropriate to undertake other more invasive investigations aimed towards making a diagnosis in utero. The fetal karyotype can be obtained by amniocentesis or cordocentesis. Cordocentesis has the advantages that a more rapid karyotype is obtained and in addition fetal viral studies, ${ }^{18}$ haemoglobin concentration, haemoglobin electrophoresis, ${ }^{19}$ and blood groups can be included. ${ }^{20}$ If the fetus is anaemic, intrauterine transfusion may be appropriate. Placental biopsy offers the advantage of a rapid karyoptype. ${ }^{21}$

The information provided by the detailed ultrasound scan may direct the clinician toward appropriate fetal treatment. An example is the considerable success with the use of maternal digoxin ${ }^{16}$ or flecainide ${ }^{22}$ to treat fetal tachyarrhythmias. Fetal thoracocentesis (and insertion of pleuroamniotic shunts) or abdominal paracentesis have also been advocated to decompress these cavities and thereby limit pulmonary hypoplasia. ${ }^{14}$

There is a higher incidence of obstetric complications at delivery, especially vaginal delivery. ${ }^{23}$ The decision to undertake elective caesarean section will, among other obstetric considerations, depend on the cause of the hydrops, the degree of severity, and the likelihood of a favourable outcome. The decision to deliver the infant early must only be undertaken when there is consensus between the obstetrician and the paediatrician that this is significantly likely to improve outcome. The hazards of preterm delivery, in addition to hydrops, should not be taken lightly and we have seen spontaneous intrauterine resolution of fetal ascites and pericardial effusions observed during the middle trimester. ${ }^{24}$ Unfortunately, stillbirth is common, ${ }^{4}$ spontaneous preterm delivery may occur, and the infant is often small for gestational age.

\section{Paediatric aspects}

Antenatal diagnosis allows delivery in a controlled setting, sometimes by elective caesarean section, with a neonatal team in attendance. The neonatal team should ensure in advance that fresh cytomegalovirus negative, $\mathrm{O}$ negative blood is available, cross matched against the mother. Exchange transfusion and full monitoring equipment should also be ready. Arterial blood pressure and central venous pressure transducers should be set up and calibrated before the baby is born. Initial resuscitation may be difficult for three main reasons. Pulmonary hypoplasia is present in $90 \%{ }^{3}$ as a result of lung compression by pleural fluid ${ }^{25}$ or gross abdominal ascites. Intrapartum asphyxia is also common. ${ }^{6}$ In addition, endotracheal intubation may be difficult because of laryngeal oedema.

\section{IMMEDIATE NEONATAL MANAGEMENT}

The infant almost always requires intubation ${ }^{4}$ and should be ventilated initially with high pressures (for example $30 \mathrm{~cm} \mathrm{H}_{2} \mathrm{O}$ ) and positive end expiratory pressure of $4-8 \mathrm{~cm}$ $\mathrm{H}_{2} \mathrm{O}$. It is often difficult to establish intravenous access because of the skin oedema and so there should be a low threshold for umbilical vein catheterisation. Pleural effusions and ascites should be drained in the delivery room if severe and obstructing respiration. ${ }^{3}$ A pericardial effusion should only be drained if there is frank tamponade.

\section{Thoracocentesis}

Ventilation is briefly stopped. A 21 gauge butterfly needle attached to a three way tap and $50 \mathrm{ml}$ syringe is inserted in the midaxillary line, fourth intercostal space, immediately above the rib and aspirated while being advanced, until fluid is obtained. Ventilation is

Table 3 Neonatal investigation of non-immune hydrops

A. Blood

1. $2 \mathrm{ml}$ in lithium heparin tube for:

(a) Urea, electrolytes, and creatinine

(b) Total protein, albumin, and protein electrophoresis

(c) Liver function tests

(d) Bilirubin: conjugated and unconjugated

(e) Osmolality

2. $0.5 \mathrm{ml}$ in EDTA tube for:

(a) Packed cell volume

(b) Full blood count

(c) Film

(c) Blood group and direct Coombs test

(e) Haemoglobin electrophoresis

3. $2 \mathrm{ml}$ in clotted tube for:

(a) TORCH screen and paravovirus titre, including specific IgM

(b) Venereal Disease Research Laboratory test (usually already performed antenatally on the mother)

4. $2 \mathrm{ml}$ in lithium heparin tube for:

Karyotype

5. Check reagent strip for blood sugar

B. Urine drome

C. Ascitic or pleural fluid

1. Sterile container for total protein and albumin

. Sterile container for lipid analysis to exclude chylous effusion

3. Sterile containers for microbiology and virology cultures

4. Lithium heparin tube to cytogenetics for karyotype

D. Chest radiograph

E. Electrocardiogram with rhythm strip

F. Ultrasound scans of heart, kidneys, and brain 
then recommenced and aspiration continued until no further fluid is obtained. The volume aspirated is noted and the fluid saved for further investigation (see table 3). Pneumothorax may occur if the lung is damaged during this procedure - a chest drain should be inserted immediately. Syncope or bradycardia may occur if fluid is removed too quickly. Ideally, the heart rate should be monitored throughout the procedure.

\section{Abdominal paracentesis}

The lower borders of the liver and the spleen should be determined by palpation. A 21 gauge butterfly needle is inserted at the midpoint of a line drawn from the umbilicus to the left anterior superior iliac spine. The volume of fluid aspirated is noted and the fluid saved for investigation (see table 3).

\section{Pericardiocentesis}

A 25 gauge needle is inserted immediately under the xiphisternum and advanced upward, backward, and laterally aiming for the tip of the left shoulder, aspirating continuously. The pericardial sac should be entered within 1-2 $\mathrm{cm}$. This can be done under echocardiographic guidance. An electrocardiograph lead attached with a crocodile clip to the proximal end of the needle will show an injury potential if contact is made with the myocardium. The fluid should be sent for investigation (table 3 ).

When the infant has been stabilised, he or she can be transferred to the neonatal unit for further assessment. If there are severe associated congenital abnormalities, this may be an appropriate stage at which to consider, in conjunction with the parents, withdrawal of active treatment. Otherwise, an umbilical venous catheter should be inserted, ensuring that the tip is above the diaphragm and in the right atrium so that the pressure measured is the true central venous pressure and not the intraabdominal pressure. If the central venous pressure is greater than $12 \mathrm{~mm} \mathrm{Hg}(16 \mathrm{~cm}$ $\mathrm{H}_{2} \mathrm{O}$ ), blood should be removed in $10 \mathrm{ml}$ aliquots until the central venous pressure is less than $6 \mathrm{~mm} \mathrm{Hg}{ }^{26}$ The central venous pressure may fall further if the $\mathrm{pH}$ and arterial oxygen tension $\left(\mathrm{PaO}_{2}\right)$ improve. If anaemia is the cause of the hydrops, partial exchange transfusion with packed cells is indicated. It may be necessary to complete the transfusion with a volume deficit if the central venous pressure remains above $12 \mathrm{~mm} \mathrm{Hg}$.

An umbilical artery catheter is inserted and the ventilation and inspired oxygen concentra-

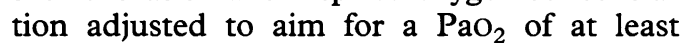
$8 \mathrm{kPa}$. As the pulmonary oedema decreases, the initial high inspiratory pressures and positive end expiratory pressure may obstruct the pulmonary circulation and therefore a reduction in pressure may aid oxygenation paradoxically. If metabolic acidosis is severe ( $\mathrm{pH}$ less than $7 \cdot 1$ ), sodium bicarbonate should be given slowly as the extracellular fluid space is already expanded and there may be incipient or overt heart failure. Initially, a dopamine infusion $(10 \mu \mathrm{g} / \mathrm{kg} / \mathrm{min})$ is preferable to a plasma expander if blood pressure support is required. Once the infant has been stabilised, colloid is appropriate if the investigations show hypoproteinaemia ${ }^{6}$ but must be given slowly. In theory, each $2 \mathrm{ml} / \mathrm{kg}$ of $25 \%$ albumin will raise the plasma albumin by $5 \mathrm{~g} / \mathrm{l}$ and this carries less risk of acute hypervolaemia than if larger volumes of $4 \%$ human albumin are used. Moderate fluid restriction (two thirds of recommended maintenance) ${ }^{27}$ and diuretics (frusemide $1 \mathrm{mg} / \mathrm{kg}$ and spironolactone 1 $\mathrm{mg} / \mathrm{kg}$, both twice a day) are employed initially. ${ }^{6}$ Coagulation studies should be checked daily, initially, as disseminated intravascular coagulopathy may ensue.

\section{POSTNATAL INVESTIGATION OF NON-IMMUNE HYDROPS FETALIS}

The minimum investigations are listed in table 3. The sample volumes required may differ from laboratory to laboratory, as may the normal ranges. Normal ranges may also vary with gestation. ${ }^{28}$ Despite full investigation, a number of infants may remain in whom no cause for the hydrops can be found. Nevertheless, investigations in these infants may give a clue as to prognosis (see below). ${ }^{4}$

\section{NEONATAL OUTCOME}

Hydrops fetalis detected in the first and second trimesters may resolve by term (for example Turner's syndrome). Many of those detected by midtrimester ultrasound scan will not be liveborn as some of the pregnancies will be electively terminated and others will be stillborn. In approximately $50 \%$ of cases, no cause is found. The mortality in different series ranges from 50-95\%,34929 partly depending on the severity of the hydrops, ${ }^{29}$ the cause and the serum protein concentrations at birth. ${ }^{4}$ The mortality is lower if the hydrops is due to fetal supraventricular tachycardia that responds to maternal treatment. The recurrence risk is low, ${ }^{23}$ unlike isoimmune hydrops fetalis.

\section{Procedure for stillbirth or neonatal death} If the infant is stillborn or dies in the immediate neonatal period, as many of the maternal and neonatal investigations as possible should be done as specified in this protocol (see tables 2 and 3 ). It is highly desirable that a full postmortem examination is performed, as soon as possible after death, in order to determine the cause of the hydrops and to assist counselling of the family with regard to future pregnancies. Parental permission should be sought for a full postmortem examination. If the parents do not wish a full postmortem to be performed, a limited postmortem may be carried out. Ensure that the limitations are annotated on the request form.

If the parents do not wish a limited postmortem examination to be performed, an attempt to gain permission for skin biopsy and needle biopsy of the liver should be made. The 
skin specimen should be placed in sterile saline and sent to the cytogenetics department. Inform the staff that a skin biopsy is on its way and that it is for fibroblast culture and karyotype. If the infant dies out of hours, the biopsy specimen should still be taken but placed in saline in a refrigerator until the laboratory is open. Ensure that the specimen reaches the laboratory at the earliest possible time. The liver cores should be snap frozen in liquid nitrogen and stored at $-70^{\circ} \mathrm{C}$. One core should be sent for routine histopathology.

Other helpful investigations are skeletal radiographs and clinical photographs. The placenta should be sent fresh to the histopathologist in all cases and not placed in formalin. If out of hours, the placenta may be stored in a conventional refrigerator overnight.

\section{Conclusion}

Care must be taken to distinguish between the causes of hydrops in the midtrimester fetus and the liveborn infant when considering the many published associations. Experience will also vary depending on whether the centre practises termination of pregnancy and on the ethnic and religious mix of the population. Our experience is that chromosomal abnormalities are now uncommonly seen as a cause of hydrops in the live newborn and that, despite extensive investigation in life and at postmortem, the underlying explanation may remain elusive.

1 Macafee CAJ, Fortune DW, Beischer NA Nonimmunologic hydrops fetalis. Br $\mathcal{f}$ Obstet Gynaecol 1970; 77: 226-37.

2 Maidman JE, Yeager C, Anderson V, et al. Prenatal diagnosis and management of nonimmunologic hydrops fetalis. Obstet Gynecol 1980; 56: 571-6.

3 Hutchison AA, Drew JH, Yu VYH, Williams ML, Fortune DW, Beischer NA. Non-immunologic hydrops fetalis: a review of 61 cases. Obstet Gynecol 1982; 59: 347-52.

4 Iliff PJ, Nicholls JM, Keeling JW, Gough JD. Non-immunologic hydrops fetalis: a review of 27 cases. Arch Dis Child 1983; 58: 979-82.

5 Salzman DH, Frigoletto FD, Harlow BL, Barss VA, Benacerraf BR. Sonographic evaluation of hydrops fetalis. Obstet Gynecol 1989; 74: 106-11.

6 Giacoia GP. Hydrops fetalis (fetal edema). Clin Pediatr (Phila) 1980; 19: 334-9.
7 Keeling JW, Gough DJ, Iliff P. The pathology of non-rhesus hydrops. Diagnostic Histopathology 1983; 6: 89-111.

hydrops. Diagnostic Histopathology 1983; 6: 89-111.
Pesonen E, Haavisto H, Ammala P, Teramo K. Intrauterine Pesonen $E$, Haavisto $H$, Ammala $P$, Teramo $K$. Intrauterine
hydrops caused by premature closure of the foramen ovale. Arch Dis Child 1983; 58: 1015-6.

9 Holzgreve W, Curry CJR, Golbus MS, Callen PW, Filly RA, Smith JC. Investigation of nonimmune hydrops fetalis. Am f Obstet Gynecol 1984; 150: 805-12.

10 Windebank KP, Bridges NA, Ostman-Smith I, Stevens JE. Hydrops fetalis due to abnormal lymphatics. Arch Dis Child 1987; 62: 198-200.

11 Jauniaux E, Van Maldergem L, De Munter C, Moscos G, Gillerot Y. Nonimmune hydrops fetalis associated with genetic abnormalities. Obstet Gynecol 1990; 75: 568-72.

12 Van Maldergem L, Jauniaux E, Fourneau C, Gillerot Y. Genetic causes of hydrops fetalis. Pediatrics 1992; 89: 81-6.

13 Im SS, Rizos N, Joutsi P, Shime J, Benzie RJ. Nonimmunologic hydrops fetalis. Am $\mathcal{f}$ Obstet Gynecol 1984; 148: 566-9.

14 Holzgreve W, Holzgreve B, Curry CJR. Nonimmune hydrops fetalis: diagnosis and management. Semin Perinatol 1985; 9 (2): 52-67.

15 Devore GR, Acherman RJ, Cabal LA, Siassi B, Bieniarz A, Platt LD. Hypoalbuminaemia: the etiology of antenatally diagnosed pericardial effusion in rhesus-hemolytic disease. Am Obstet Gynecol 1982; 142: 1056-7.

16 Kleinman CS, Donnerstein RL, DeVore GR, et al. Fetal echocardiography for evaluation of in utero congestive heart failure. A technique for study of nonimmune fetal hydrops. $N$ Engl $\Im$ Med 1982; 306: 568-75.

17 Tuberville DF, Killam AP, Davis PC, Heath RE, Fearnow RG, Pearson JW. Non-immunologic hydrops fetalis. Obstet Gynecol 1974; 43: 567-70.

18 Peters MT, Nicolaides KH. Cordocentesis for the diagnosis and treatment of human parvovirus infection. Obstet Gynecol 1990; 75: 501-4.

19 Beaudry MA, Ferguson DJ, Pearse K, Yanofsky RA, Rubin EM, Kan WY. Survival of hydropic infant with homozygous alpha-thalassemia. $\mathcal{f}$ Pediatr 1986; 108: 713-6.

20 Nicolaides $\mathrm{KH}$, Rodeck $\mathrm{CH}$, Millar DS, Mibashan RS. Fetal haematology in rhesus isoimmunisation. BMf 1985; 290: 661-3.

21 Rosevear S. Placental biopsy. Br $f$ Hosp Med 1989; 41: 334-48.

22 Allan LD. Diagnosis of fetal cardiac abnormalities. Arch Dis Child 1989; 64: 964-8.

23 Gough JD, Keeling JW, Castle B, Iliff PJ. The obstetric management of non-immunological hydrops. $\mathrm{Br} \mathcal{F}$ Obstet Gynaecol 1986; 93: 226-34

24 Platt LD, Collea JV, Joseph DM. Transitory fetal ascites: an ultrasound diagnosis. Am $\mathcal{F}$ Obstet Gynecol 1978; 132: 906-8.

25 Van Aerde A, Campbell AN, Smyth JA, Lloyd D, Bryan HM. Spontaneous chylothorax in newborns. Am $\mathcal{F}$ Dis Child 1984; 138: 961-4.

26 Skinner JR, Milligan DWA, Hunter S, Hey EN. Central venous pressure in the ventilated neonate. Arch Dis Child 1992; 67: 374-7.

27 Stephenson TJ, Rutter N. Fluid balance. In: McIntosh N, Campbell AGM, eds. Forfar and Arneil's textbook of paediatrics. 4th Ed. London: Churchill Livingstone, 1992: 158-65.

28 Cartlidge PHT, Rutter N. Serum albumin concentrations and oedema in the newborn. Arch Dis Child 1986; 61: 657-60.

29 Etches PC, Lemons JA. Non-immune hydrops fetalis: report of 22 cases including 3 siblings. Pediatrics 1979; 64: 326-32. 